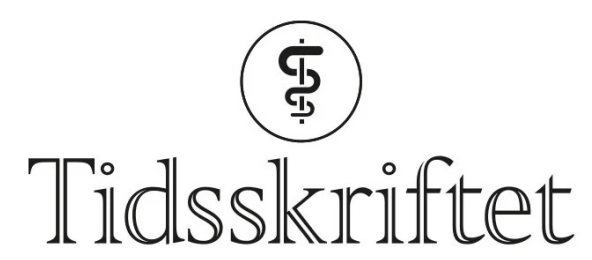

DEN NORSKE LEGEFORENING

\title{
Åsmund Ragnar Reikvam
}

\author{
MINNEORD
}

FINN OLAV LEVY

HEGE SALVESEN BLIX

JON BIRGER HAUG

ANNE-KARI HOLM

TOR SKOMEDAL

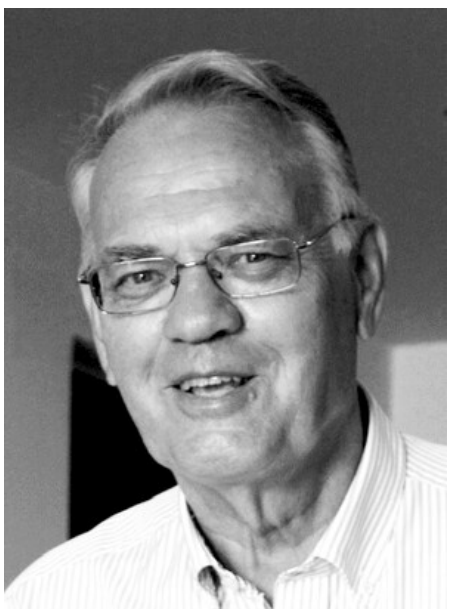

Professor emeritus Åsmund Reikvam døde 12. desember 2020 etter lengre tids sykdom, 76 år gammel. Den alltid korrekte og velforberedte hjertespesialisten, overlegen, sjefslegen, forskningslederen, lokalpolitikeren og farmakologen er ikke lenger blant oss.

Han vokste opp i Førde og ble utdannet lege i Oslo 1970. Etter doktorgrad i fysiologi i 1976 spesialiserte han seg i indremedisin og hjertesykdommer, hovedsakelig ved Ullevål sykehus. I 1981 flyttet han tilbake til hjemfylket, der han i en tiårsperiode var overlege ved Sogn og Fjordane sentralsjukehus i Førde. Han var også sjefslege samme sted i perioden 1989-91. Han hadde sine meningers mot, var lokalpolitiker og hadde flere verv i Legeforeningens lokallag og landsstyre. Han kjempet hardt for det han trodde på. 
I tillegg til sitt kliniske virke var han svært forskningsinteressert og har en stor vitenskapelig produksjon. Han var medlem i internasjonal styringsgruppe og nasjonal koordinator for flere store hjerteforskningsstudier, deriblant ISIS-2, som ble førende for behandling av hjerteinfarkt med acetylsalisylsyre og trombolyse. Han var i mange år sentral i forskningsevaluering og fordeling av forskningsmidler, blant annet gjennom arbeid i Norges forskningsråd, forskningsforum Ullevål sykehus og Extrastiftelsen (nå Stiftelsen DAM), der han i nesten 20 år la premissene for og var med på fordeling av over 1 milliard kroner til klinisk forskning.

I 1999 ble han professor og i 2005 leder for Institutt for farmakoterapi, til dette i 2008 ble slått sammen med Farmakologisk institutt (nå Avdeling for farmakologi) ved Universitetet i Oslo og Oslo universitetssykehus. Hans forskningsfelt i denne perioden var riktig bruk av legemidler i sykehus og i samfunnet. Han veiledet flere stipendiater til doktorgrad, deriblant flere farmasøyter, og bidro gjennom dette til etablering av klinisk farmasi i Norge. Han var i flere år ansvarlig for kurset Farmakoterapi i allmennpraksis og en mye brukt veileder om warfarin-behandling.

Han var faglig oppdatert og hadde en unik evne til å se og fange den røde tråden, selv i felt han ikke var helt hjemmehørende i. Åsmund var lyttende og hadde alltid tid. Han hadde ekstremt god språkforståelse og var opptatt av at artiklene skulle skrives godt for å få betydningen av forskningen klart frem.

Han var korrekt, høflig og hyggelig, med stor omtanke for sine medarbeidere. Han var helstøpt og til å stole på, en hedersmann.

Våre tanker går til hans kone Bente, hans barn, barnebarn og øvrige familie, som har mistet sin kjære. Vi lyser fred over Åsmund Reikvams minne.

Publisert: 22. februar 2021. Tidsskr Nor Legeforen. DOI:10.4045/tidsskr.21.0041

(C) Tidsskrift for Den norske legeforening 2023. Lastet ned fra tidsskriftet.no 26. april 2023. 